\title{
Change management practices to support the implementation of lean production systems: a survey of the scientific literature
}

\author{
Práticas de gestão de mudança para apoiar a implantação de \\ sistemas de produção enxuta: um levantamento da \\ literatura científica

\begin{abstract}
Isadora Avelar Ferreira ${ }^{1}$, Fernando Oliveira de Araujo ${ }^{1}$ (D), Márcia Elisa Soares Echeveste ${ }^{2}$ (D)
${ }^{1}$ Universidade Federal Fluminense - UFF, Departamento de Engenharia de Produção, Niterói, RJ, Brasil. E-mail: isadoraavelar@id.uff.br; fernandoaraujo@id.uff.br

${ }^{2}$ Universidade Federal do Rio Grande do Sul - UFRGS, Instituto de Matemática, Departamento de Estatística, Porto Alegre, RS, Brasil. E-mail: echeveste.mar@gmail.com
\end{abstract}

How to cite: Ferreira, I. A., Araujo, F. O., \& Echeveste, M. E. S. (2020). Change management practices to support the implementation of lean production systems: a survey of the scientific literature. Gestão \& Produção, 27(2), e4019. https://doi.org/10.1590/0104-530X4019-20

\begin{abstract}
The transition from mass production system to lean production system carrier significant changes in operational strategies of industrial organizations. A production model system can engender different reactions by the people involved; some of them can show resistance during the process, ranging from unreserved support to a hidden resistance (even explicit). In order to identify the main practices to support change processes, this study provides a literature review to systematize the main researches related to change management during lean manufacturing implementation. This study aims to provide a systematic literature review covering main researches related to change management and lean manufacturing implementation to identify the main factors that affect the production system change. The research was carried out between October 2016 and January 2018. In methodological terms, literature review was developed by using Scopus and ISI web of Science publications. As a result of this study, 25 papers related to lean manufacturing implementation were identified and 10 factors were consolidated. The most relevant practices of change management were also identified to support lean production system implementation.
\end{abstract}

Keywords: Lean manufacturing; Change management; Contributing factors of lean manufacturing systems implementation.

Resumo: A transição de um sistema de produção em massa para um sistema de produção enxuta implica em mudanças de grande magnitude no âmbito da estratégia de operações por parte de organizações de base de manufatura, podendo desencadear diferentes reações por parte dos colaboradores, indo desde o apoio irrestrito à iniciativa até a resistência velada (ou mesmo explícita). No sentido de identificar as principais práticas capazes de apoiar essas mudanças, o presente estudo tem o objetivo de oferecer uma revisão da literatura de modo a sistematizar as principais pesquisas realizadas sobre a gestão de mudança relacionada à implantação do lean manufacturing. Em especial, o estudo tem o propósito de evidenciar os principais fatores que podem comprometer e ou potencializar o êxito da adoção dos princípios

Received May 23, 2017 - Accepted Feb 28, 2018

Financial support: None. 
lean no sistema de produção. A pesquisa foi realizada no período de Outubro de 2016 a Janeiro de 2018 nas bases de periódicos Scopus e ISI Web of Science para identificação dos principais periódicos, autores e sua literatura concernente à temática. Como resultados, foram identificados 25 artigos provenientes das referidas bases, o que permitiu a consolidação de 10 fatores-chave na literatura e a identificação das práticas de gestão de mudança relevantes para apoiar a implantação de sistemas de produção enxuta.

Palavras-chave: Produção enxuta; Gestão de mudança; Fatores contributivos à implantação de sistemas de produção enxuta.

\section{Introduction}

The mass and lean production systems have different organizational cultures. The mass system is characterized by the use of professionals specialized in designing products that are standardized by non-qualified workers; high cost machines performing one activity and generating excessive production stocks; higher number of indirect workers to control production; furthermore quality inspection is performed at the end of the assembly line generating rework.

In the lean production system, work is performed only with necessary resources, rationalizing aspects such as manufacturing space, stocks and workers efforts (Womack et al., 1997). The work is standardized and the operators follow process rhythm, therefore the activity time is shorter. The process also results in fewer defects, as quality inspection is performed with the production flow. The production requires more professional qualifications in a team environment (Womack et al., 1997).

Different production systems have different demands on the worker profile, thus is relevant to consider that change process in manufacturing systems must consider the transition of aspects and impacts of a previous modus operandi in the future, since professionals with different characteristics and personalities influence the attitudes, behaviors and level of engagement of the company As observed by Walker et al. (2007), these differences create distinct perspectives about the lean transition process and may result in resistance or acceptance behaviors.

Lines et al. (2015) observed resistance by workers in their studies related to transition projects although these initiatives presented different scopes and the companies studied different sizes. Maheshwari \& Vohra (2015) argue that employees' behavior and attitudes are influenced by these workers' perceptions of the change process and that they may have a positive perception, with willingness to change, or a negative, demonstrating resistance to the process.

Taking into account the diversity of approaches concerning the management of change and the scarcity of studies which offer a comprehensive systematization, especially in relation to lean production systems, the present study aims to answer the following research questions: Does the scientific literature offer studies about change management practices to support the deployment of lean production systems? If yes, what are the main practices highlighted in academic studies?

Thus, the present work aims to identify, through a systematic review of the literature, the main factors that interfere with the success of change management during the lean manufacturing deployment process.

In terms of organization, the paper is subdivided into six sections: the first provides a brief introduction on the subject in addition to establishing the boundaries of the study; the second section presents a preliminary discussion about the themes change management and lean production system; the methodological procedures adopted in 
the research is described in the third section; the fourth section comprises the systematic analysis results and the fifth the discussion of the results obtained; and finally the sixth section presents the conclusions of the study and suggestions for future research.

\section{Change management and lean production systems}

The Toyota Production System (TPS) based on lean thinking, is highlighted in the literature as one of the most efficient production systems for industry-based companies (Furlan et al., 2011; Hasle, 2014; Bamford et al., 2015; Shokri et al., 2016). The system is characterized by the identification and elimination of wastes, qualified workers, flexible and automated machines for production of large volumes with high variability (Womack \& Jones, 1994).

Lean production system enables to specify value, align the sequence of added-value activities, eliminate wastes and produce without any interruptions, resulting also in fewer workers efforts, space occupied and machines time but attending customer needs (Womack \& Jones, 2003; Liker, 2004).

It is important to consider that a production system implementation is not limited to technical and technological change; it also requires the engagement of the interested members of the company to ensure successful deployment. The non-involvement of the workers may result in resistance behaviors (Parish et al., 2008; Goodman \& Loh, 2011; Chu, 2003; Van Dun et al., 2016). Therefore, the biggest challenge of lean implementation is to change behavior and mentality of the workers and managers (Womack, 2011).

For Battilana et al. (2010), the three main activities associated with the lean transition process are: (i) Communicating the change need; (ii) Mobilizing people to support the change; (iii) Evaluating the implementation of the process.

In their study, Armenakis \& Bedeian (1999) observe the existence of three common factors to the change processes: the characteristics and context of the company and the organization of processes. Walker et al. (2007) suggest another important factor: the cultural differences among workers within an organization.

Organizational change refers primarily to changes in the lean staff itself, so team leaders must first understand the changes and their implications for people and then listen to the workers in order to understand the reasons behind the resistance (Goodman \& Loh, 2011). Reliable relationships can be considered as a key factor for organizational success, especially in terms of human resources (Morgan \& Zeffane, 2003).

Studies by Hill et al. (2012) indicated that the operators had a high level of commitment working with managers who presented the most transformative leadership style. According to the authors, transformative leaders motivate their followers to go beyond a vision in their personal interests towards a view of collective interests.

For Lines et al. (2015), the existence of a person specifically in charge of the lean transition implementation who has a clear understanding of the entire change framework assists in the process of knowledge transfer.

Rusly et al. (2015) observed the need to develop so that the implemented changes may succeed. The authors defined six categories, distributed at the individual and organizational levels, related to the process of knowledge acquisition. At the individual levels, four categories were considered: (i) Knowledge need; (ii) Management support; 
(iii) Knowledge, and (iii) Adaptability. At the organizational level, two categories were considered: (i) Learning and (ii) Communication.

Achieving knowledge at individual levels involves the ability to recognize, assimilate and apply new information. This process requires a receiver who is capable of integrating this new knowledge into his pre-existing base. Professionals who are not capable of such integration find it difficult to adjust for change (Rusly et al., 2015). At the organizational level, learning can be developed through the use of training and coaching programs.

Furthermore, an efficient communication is also considered to be relevant in order to improve interactions and knowledge transfer to workers who must be aware of the change vision, the people involved and how to proceed with their actions (Box \& Platts, 2005; Rusly et al., 2015). According to Kotter (1997), managers do not communicate well or inadvertently send inconsistent messages, resulting in the interruption of the transformations.

In order to develop teamwork and engagement, there must be a mix between the two types of communication: top-down - communication performed from the upper levels of an organization to the lower levels; and bottom-up - communication from the lower to the higher levels (Hill et al., 2012).

Successful implementation of lean manufacturing process will also depends on a change management that reflects on corporate culture. The establishment of new methods in the organization culture allows changes not to be deteriorated when the pressure on the process decreases (Kotter, 1997). A new culture should be developed within the organization so that people feel willing to contribute to the success of the implementations (Chu, 2003; Shook, 2010); in this perspective, the resistance can be understood as a constructed reality in which the individuals operate (Ford et al., 2002).

\section{Methodological procedures}

The webbliomining, model proposed by Costa (2010) was used as the basis to collect the research data. It performs a preliminary analysis of the bibliographical references available through the evaluation of statistical data. By using this model, it is possible to select the preliminary papers for the bibliographical research (Silva \& Costa, 2015).

In this paper, the model followed the steps: (i) Definition of the search sample; (ii) Sample search with keywords; (iii) Search refinement; (iv) Selection of papers to compound the starting point (core, nucleus); (v) Analysis of the starting nucleus: chronological survey and analysis of research sources; (vi) Identification of the contributory factors related to the change process.

\subsection{Definition of search sample}

The defined search sample corresponds to papers indexed in the Scopus (Elsevier) and ISI Web of Science (Thomson Reuters Scientific) databases accessed through the Capes periodicals portal from October 2016 to January 2018. These databases were selected because they are libraries of publications with great volume, variety of content, accessibility and tools for effective searches. 


\subsection{Searching the sample with keywords}

The researches in the databases began with the definition of the keywords and the string of research by using boolean connectors OR and AND.

- (Produção enxuta OR Lean manufacturing) AND (Gestão de mudança OR Change management).

In addition to the keywords, the search refinement filters were initially added. In the case of the Scopus database an area search filter was also inserted (Physical Science; Social Sciences \& Humanity). Table 1 systematizes the information in the search fields of the two databases:

Table 1. Completion of the search field.

\begin{tabular}{ccc} 
Search Fields & \multicolumn{2}{c}{ SCOPUS and ISI Web of Science } \\
\hline \multirow{3}{*}{ String of research } & \multicolumn{2}{c}{ lean manufacturing } \\
\cline { 2 - 3 } & OR & Produção enxuta \\
\cline { 2 - 3 } & AND & Change management \\
\hline Types of search (SCOPUS) & OR & Gestão de mudança \\
\hline Types of search (ISI) & & Article Title, Abstract, Keywords \\
\hline
\end{tabular}

Source: Scopus database and Web of Science.

\subsection{Search refinement}

After the first search, 523 documents from the Scopus database and 2915 from the ISI Web of Science database were identified. Afterwards, filters were selected to improve the refinement of the search such as subject area, languages and document types (Table 2).

Table 2. Search refinement fields.

\begin{tabular}{ccc}
\hline Search Field & Scopus & ISI Web of Science \\
\hline \multirow{3}{*}{ Area of research } & Engineering & Engineering Manufacturing \\
\cline { 2 - 3 } & $\begin{array}{c}\text { Business, management and } \\
\text { accounting }\end{array}$ & Engineering Industrial \\
\cline { 2 - 3 } Languages & English & Mngineering multidisciplinar \\
\cline { 2 - 3 } & Portuguese & English \\
\hline \multirow{2}{*}{ Document types } & Article & Prticle \\
\cline { 2 - 3 } & Review & Review \\
\hline
\end{tabular}

Source: Scopus database and Web of Science.

After refinement, 224 papers of the Scopus base and 1025 of the ISI Web of Science database were identified. 


\subsection{Sorting and selection of the papers procedures to set up the starting nucleus}

The refinement of the abstracts according to the research objectives used as criteria papers that discussed about the implementation of lean manufacturing system in organizations and the impacts related to the transition management process.

Considering the screening of the documents from the two databases, 25 papers were identified in line with the research objective, 14 of which were selected from the Scopus database and 11 from the ISI Web of Science database.

The systematization of contributing factors to the transition process was carried out through the content analysis proposed by Bardin (1977) during the cataloging process and deep analysis of the works (deep reading).

Figure 1 illustrates the process of searching, systematizing and analyzing works from the Scopus and ISI Web of Science databases.

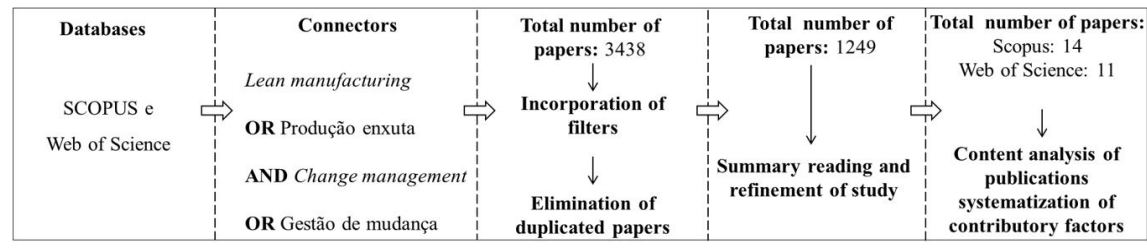

Figure 1. Summary of searches in databases. Source: Authors.

Table 3 summarizes the papers related to the research objective, according to previously defined criteria, in descending order of the number of quotes.

Table 3. Selected papers from the Scopus and Web of Science databases.

\begin{tabular}{|c|c|c|c|c|}
\hline & Name & Authors/Years & Source & $\begin{array}{c}\mathrm{N}^{0} \text { of } \\
\text { quotes }\end{array}$ \\
\hline 1 & $\begin{array}{l}\text { Lean manufacturing: Context, } \\
\text { practice bundles, and } \\
\text { performance }\end{array}$ & $\begin{array}{l}\text { Shah \& Ward } \\
\qquad(2003)\end{array}$ & $\begin{array}{l}\text { Journal of Operations } \\
\text { Management }\end{array}$ & 969 \\
\hline 2 & $\begin{array}{l}\text { The benefits of lean } \\
\text { manufacturing: What lean } \\
\text { thinking has to offer the process } \\
\text { industries }\end{array}$ & Melton (2005) & $\begin{array}{l}\text { Chemical Engineering } \\
\text { Research and Design }\end{array}$ & 172 \\
\hline 3 & $\begin{array}{l}\text { A business process change } \\
\text { framework for examining lean } \\
\text { manufacturing: A case study }\end{array}$ & Motwani (2003) & $\begin{array}{l}\text { Industrial Management } \\
\text { and Data Systems }\end{array}$ & 85 \\
\hline 4 & $\begin{array}{l}\text { An appropriate change strategy } \\
\text { for lean success }\end{array}$ & Bhasin (2012) & Management Decision & 58 \\
\hline 5 & $\begin{array}{l}\text { Human performance in lean } \\
\text { production environment: Critical } \\
\text { assessment and research } \\
\text { framework }\end{array}$ & $\begin{array}{c}\text { Genaidy \& } \\
\text { Karwowski (2003) }\end{array}$ & $\begin{array}{l}\text { Human Factors And } \\
\text { Ergonomics In } \\
\text { Manufacturing }\end{array}$ & 53 \\
\hline 6 & $\begin{array}{l}\text { Lean indicators and } \\
\text { manufacturing strategies }\end{array}$ & $\begin{array}{l}\text { Martínez Sánchez } \\
\text { \& Pérez Pérez } \\
\text { (2001) }\end{array}$ & $\begin{array}{l}\text { International Journal of } \\
\text { Operations \& Production } \\
\text { Management }\end{array}$ & 50 \\
\hline 7 & $\begin{array}{l}\text { How do employees perceive their } \\
\text { organization, and job when } \\
\text { companies adopt principles of } \\
\text { lean production? }\end{array}$ & $\begin{array}{c}\text { Seppälä \& } \\
\text { Klemola (2004) }\end{array}$ & $\begin{array}{l}\text { Human Factors And } \\
\text { Ergonomics In } \\
\text { Manufacturing }\end{array}$ & 32 \\
\hline
\end{tabular}


Table 3. Continued...

\begin{tabular}{|c|c|c|c|c|}
\hline & Name & Authors/Years & Source & $\begin{array}{l}\mathbf{N}^{\circ} \text { of } \\
\text { quotes }\end{array}$ \\
\hline 8 & $\begin{array}{l}\text { Performance of organisations } \\
\text { treating lean as an ideology }\end{array}$ & Bhasin (2011) & $\begin{array}{l}\text { Business Process } \\
\text { Management Journal }\end{array}$ & 30 \\
\hline 9 & $\begin{array}{l}\text { A framework for organisational } \\
\text { change management in lean } \\
\text { manufacturing implementation }\end{array}$ & $\begin{array}{l}\text { Nordin et al. } \\
\quad(2012)\end{array}$ & $\begin{array}{c}\text { International Journal of } \\
\text { Services and Operations } \\
\text { Management }\end{array}$ & 23 \\
\hline 10 & $\begin{array}{c}\text { Lean production - An evaluation } \\
\text { of the possibilities for an } \\
\text { employee supportive lean } \\
\text { practice }\end{array}$ & Hasle (2014) & $\begin{array}{l}\text { Human Factors and } \\
\text { Ergonomics In } \\
\text { Manufacturing }\end{array}$ & 22 \\
\hline 11 & $\begin{array}{l}\text { Human resource management } \\
\text { strategies and practices in Just- } \\
\text { In-Time environments: Australian } \\
\text { case study evidence }\end{array}$ & $\begin{array}{l}\text { Power \& Sohal } \\
\qquad(2000)\end{array}$ & Technovation & 17 \\
\hline 12 & $\begin{array}{l}\text { Fundamental mindset that drives } \\
\text { improvements towards lean } \\
\text { production }\end{array}$ & $\begin{array}{l}\text { Yamamoto \& } \\
\text { Bellgran (2010) }\end{array}$ & Assembly Automation & 20 \\
\hline 13 & $\begin{array}{l}\text { How to identify and remove the } \\
\text { barriers for a successful lean } \\
\text { implementation }\end{array}$ & $\begin{array}{l}\text { Boyer \& Sovilla } \\
\qquad(2003)\end{array}$ & $\begin{array}{l}\text { Journal of Ship } \\
\text { Production }\end{array}$ & 15 \\
\hline 14 & $\begin{array}{l}\text { Identificação de oportunidades } \\
\text { de pesquisa a partir de um } \\
\text { levantamento da implantação da } \\
\text { produção enxuta em empresas } \\
\text { do Brasil e do exterior }\end{array}$ & $\begin{array}{l}\text { Saurin et al. } \\
\qquad(2010)\end{array}$ & Gestao e Producão & 15 \\
\hline 15 & $\begin{array}{l}\text { Impact of corporate culture on the } \\
\text { adoption of the lean principles }\end{array}$ & Bhasin (2013) & $\begin{array}{l}\text { International Journal of } \\
\text { Lean Six Sigma }\end{array}$ & 9 \\
\hline 16 & $\begin{array}{l}\text { Success factors and barriers to } \\
\text { implementing lean in the printing } \\
\text { industry: A case study and } \\
\text { theoretical framework }\end{array}$ & $\begin{array}{l}\text { Azyan et al. } \\
\text { (2017) }\end{array}$ & $\begin{array}{l}\text { Journal of Manufacturing } \\
\text { Technology Management }\end{array}$ & 4 \\
\hline 17 & $\begin{array}{l}\text { How to carry out sustainable } \\
\text { change? An analysis of } \\
\text { introducing manufacturing cells in } \\
\text { a Finnish engineering company }\end{array}$ & Seppälä (2006) & $\begin{array}{l}\text { Human Factors And } \\
\text { Ergonomics In } \\
\text { Manufacturing }\end{array}$ & 3 \\
\hline 18 & $\begin{array}{l}\text { Lean manufacturing } \\
\text { implementation: an assessment } \\
\text { method with regards to socio- } \\
\text { technical and ergonomics } \\
\text { practices adoption. International } \\
\text { Journal of Advanced } \\
\text { Manufacturing Technology, }\end{array}$ & $\begin{array}{l}\text { Tortorella et al. } \\
\qquad(2017)\end{array}$ & $\begin{array}{c}\text { International Journal of } \\
\text { Advanced Manufacturing } \\
\text { Technology }\end{array}$ & 3 \\
\hline 19 & $\begin{array}{l}\text { Lean and US manufacturing } \\
\text { industry: popularity of practices } \\
\text { and implementation barriers. }\end{array}$ & $\begin{array}{l}\text { Abolhassani et al. } \\
\qquad(2016)\end{array}$ & $\begin{array}{l}\text { International Journal of } \\
\text { Productivity and } \\
\text { Performance } \\
\text { Management }\end{array}$ & 1 \\
\hline 20 & $\begin{array}{l}\text { Lean implementation strategies: } \\
\text { how are the Toyota way } \\
\text { principles addressed? }\end{array}$ & $\begin{array}{l}\text { Coetzee et al. } \\
\qquad(2016)\end{array}$ & $\begin{array}{l}\text { South African Journal of } \\
\text { Industrial Engineering, }\end{array}$ & 1 \\
\hline 21 & $\begin{array}{l}\text { The effect of organizational } \\
\text { culture on implementing and } \\
\text { sustaining lean processes }\end{array}$ & $\begin{array}{l}\text { Pakdil \& Leonard } \\
\qquad(2015)\end{array}$ & $\begin{array}{l}\text { Journal of Manufacturing } \\
\text { Technology Management }\end{array}$ & 0 \\
\hline 22 & $\begin{array}{c}\text { Gestão da mudança para um } \\
\text { sistema de produção enxuta: } \\
\text { Estado da arte e direções de } \\
\text { pesquisa. }\end{array}$ & $\begin{array}{c}\text { Tortorella \& } \\
\text { Fogliatto (2013) }\end{array}$ & Espacios & 0 \\
\hline
\end{tabular}


Table 3. Continued...

\begin{tabular}{|c|c|c|c|}
\hline Name & Authors/Years & Source & $\begin{array}{c}\mathbf{N}^{0} \text { of } \\
\text { quotes }\end{array}$ \\
\hline $\begin{array}{c}\text { Impact of Lean Production on } \\
23 \text { Perceived Job Autonomy and Job } \\
\text { Satisfaction: An Experimental } \\
\text { Study }\end{array}$ & $\begin{array}{l}\text { Rodriguez et al. } \\
\qquad(2016)\end{array}$ & $\begin{array}{c}\text { Human Factors and } \\
\text { Ergonomics in } \\
\text { Manufacturing \& Service } \\
\text { industries }\end{array}$ & 0 \\
\hline $\begin{array}{c}\text { Employees motivation and } \\
\text { openness for continuous } \\
24 \text { improvement: comparative study } \\
\text { in polish and japanese } \\
\text { companies. }\end{array}$ & $\begin{array}{c}\text { Stadnicka \& } \\
\text { Sakano (2017) }\end{array}$ & $\begin{array}{c}\text { Management and } \\
\text { Production Engineering } \\
\text { Review }\end{array}$ & 0 \\
\hline $\begin{array}{c}\text { Critical issues in lean } \\
25 \text { manufacturing programs: A case } \\
\text { study in Kurdish iron \& steel } \\
\text { factories. }\end{array}$ & $\begin{array}{c}\text { Kareem et al. } \\
(2017)\end{array}$ & Cogent Engineering & 0 \\
\hline
\end{tabular}

Source: Authors.

\subsection{Analyzing the starting nucleus: chronological survey and analysis of research sources}

Figure 2 illustrates the chronological survey of the analyzed databases. The papers related to the scope of the present study were published between 2000 and 2018 . During this period, 2003 and 2017 presented a peak of production with 04 papers; in 2016, 3 productions were presented; and in addition to 2010, 2012 and 2013 (with two publications in each) were those with the highest amount of publications.

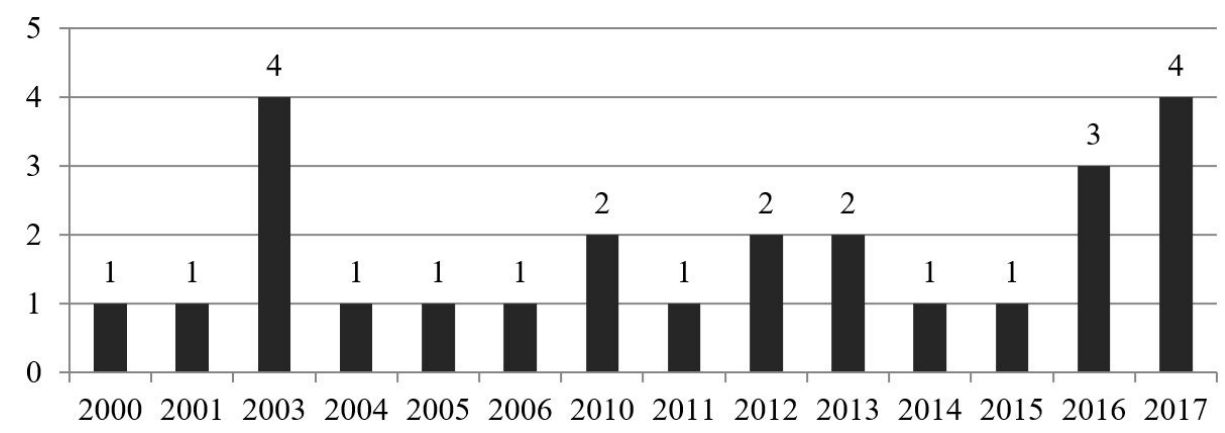

Figure 2. Number of documents per year - Selected papers. Source: Authors.

In relation to the sources of research, it can be seen that the publications on the topic are scattered in different journals. An analysis of the periodicals according to their editorial scope was also carried out as indicated in Table 4.

Table 4. Papers per Journals - Scopus e Web of Science.

\begin{tabular}{|c|c|c|c|}
\hline & Source & Quantities & Scope \\
\hline 1 & Human Factors And Ergonomics In Manufacturing & 4 & Ergonomics \\
\hline 2 & Journal of Manufacturing Technology Management & 2 & $\begin{array}{l}\text { Operations } \\
\text { Management }\end{array}$ \\
\hline 3 & $\begin{array}{l}\text { Human Factors and Ergonomics in Manufacturing \& Service } \\
\text { industries }\end{array}$ & 1 & Ergonomics \\
\hline
\end{tabular}


Table 4. Continued...

\begin{tabular}{|c|c|c|c|}
\hline & Source & Quantities & Scope \\
\hline 4 & $\begin{array}{c}\text { International Journal of Services and Operations } \\
\text { Management }\end{array}$ & 1 & $\begin{array}{c}\text { Operations } \\
\text { Management }\end{array}$ \\
\hline 5 & Business Process Management Journal & 1 & $\begin{array}{l}\text { Operations } \\
\text { Management }\end{array}$ \\
\hline 6 & Gestão e Produção & 1 & $\begin{array}{l}\text { Operations } \\
\text { Management }\end{array}$ \\
\hline 7 & International Journal of Operations \& Production Management & 1 & $\begin{array}{l}\text { Operations } \\
\text { Management }\end{array}$ \\
\hline 8 & International Journal of Lean Six Sigma & 1 & $\begin{array}{l}\text { Operations } \\
\text { Management }\end{array}$ \\
\hline 9 & Journal of Operations Management & 1 & $\begin{array}{l}\text { Operations } \\
\text { Management }\end{array}$ \\
\hline 10 & Chemical Engineering Research and Design & 1 & $\begin{array}{l}\text { Operations } \\
\text { Management }\end{array}$ \\
\hline 11 & Management Decision & 1 & $\begin{array}{l}\text { Operations } \\
\text { Management }\end{array}$ \\
\hline 12 & Espacios & 1 & $\begin{array}{l}\text { Operations } \\
\text { Management }\end{array}$ \\
\hline 13 & Industrial Management and Data Systems & 1 & $\begin{array}{l}\text { Operations } \\
\text { Management }\end{array}$ \\
\hline 14 & Journal of Ship Production & 1 & $\begin{array}{l}\text { Manufacturin } \\
\text { g systems }\end{array}$ \\
\hline 15 & Technovation & 1 & $\begin{array}{l}\text { Manufacturin } \\
\text { g systems }\end{array}$ \\
\hline 16 & Assembly Automation & 1 & $\begin{array}{l}\text { Manufacturin } \\
\text { g systems }\end{array}$ \\
\hline 17 & South African Journal of Industrial Engineering & 1 & $\begin{array}{l}\text { Operations } \\
\text { Management }\end{array}$ \\
\hline 18 & $\begin{array}{l}\text { International Journal of Productivity and Performance } \\
\text { Management }\end{array}$ & 1 & $\begin{array}{l}\text { Operations } \\
\text { Management }\end{array}$ \\
\hline 19 & Management and Production Engineering Review & 1 & $\begin{array}{l}\text { Operations } \\
\text { Management }\end{array}$ \\
\hline 20 & $\begin{array}{c}\text { The International Journal of Advanced Manufacturing } \\
\text { Technology }\end{array}$ & 1 & $\begin{array}{l}\text { Operations } \\
\text { Management }\end{array}$ \\
\hline 21 & Cogent Engineering & 1 & $\begin{array}{l}\text { Operations } \\
\text { Management }\end{array}$ \\
\hline
\end{tabular}

Source: Authors.

It was observed a greater inclination of the search sources to the area of operations management (16 journals), followed by the manufacturing systems concerning production, computer issues and programming ( 3 journals). The area of ergonomics, which deals with human aspects not specifically related to work, was observed in two journals. In contrast, the latter area concentrates 5 of the 25 selected studies (20\%).

\subsection{Identification of contributing factors to the change process}

After deep reading and identification of the main attributes of change management in lean production systems, the process of cataloging the various authors that quote the same attribute started. The analysis was performed through descriptive statistics, with the application of the Pareto graph. 
Thus, it can be deduced from this research that the most quoted attribute in the literature is possibly the most evidenced in industrial practice. Thereafter, the discussion of each factor was carried out based on the starting nucleus literature.

\section{Results of systematic analysis}

As mentioned, this research aims to identify the factors that contribute to the successful implementation of lean manufacturing system in industrial-based companies.

Through bibliometric research and use of the webibliomining method, 25 papers related to transition management practices in lean manufacturing implementation processes were identified. Table 5 systematizes the 10 relevant factors to the implementation of lean production systems.

Table 5. Systematization of the 10 factors identified in the literature related to change management in a lean manufacturing implementation process.

Factors/Authors

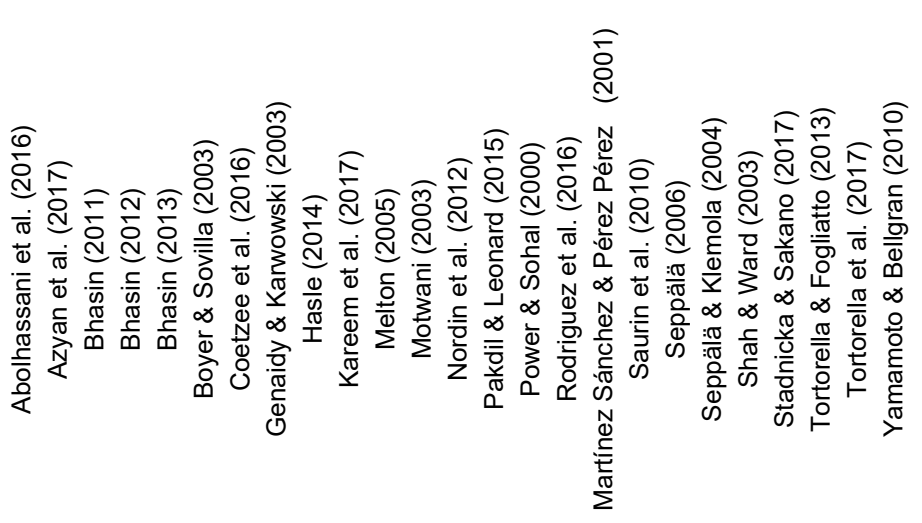

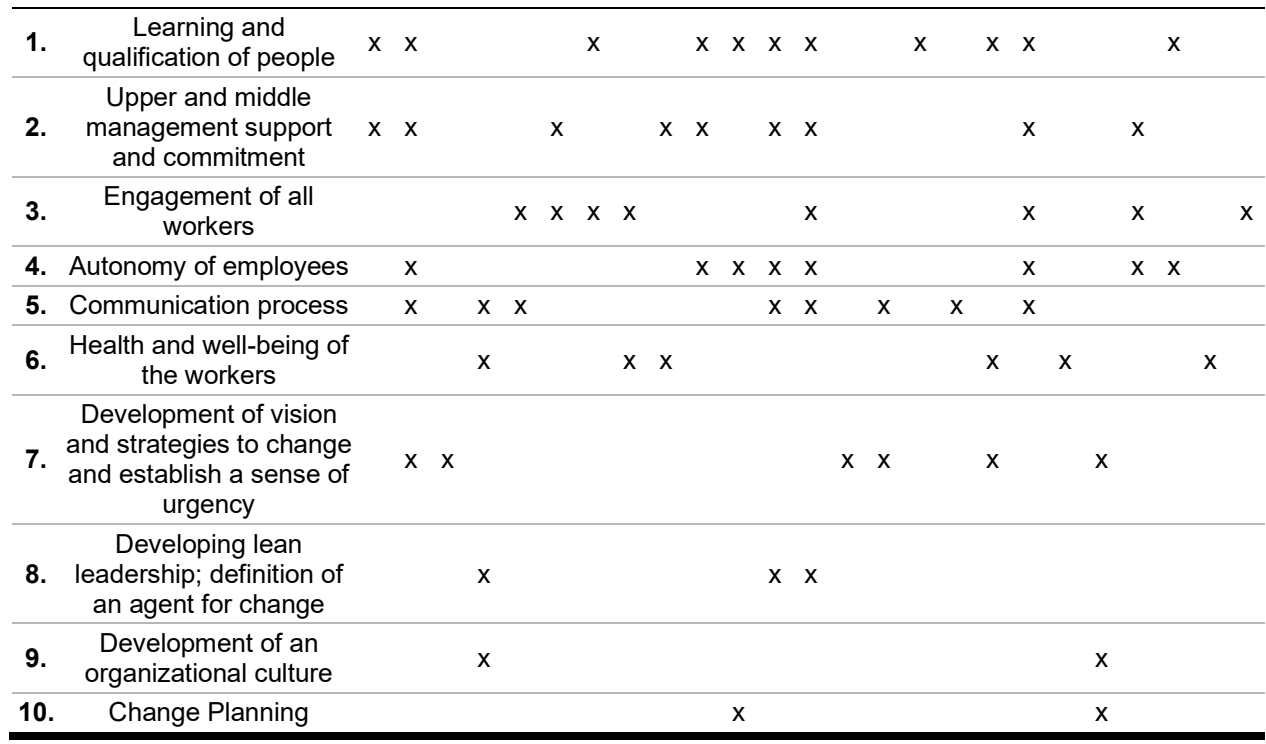

Source: Authors. 
Figure 3 illustrates the Pareto graph with the 10 factors evidenced in the literature, indicating how many times they were quoted in the selected papers.

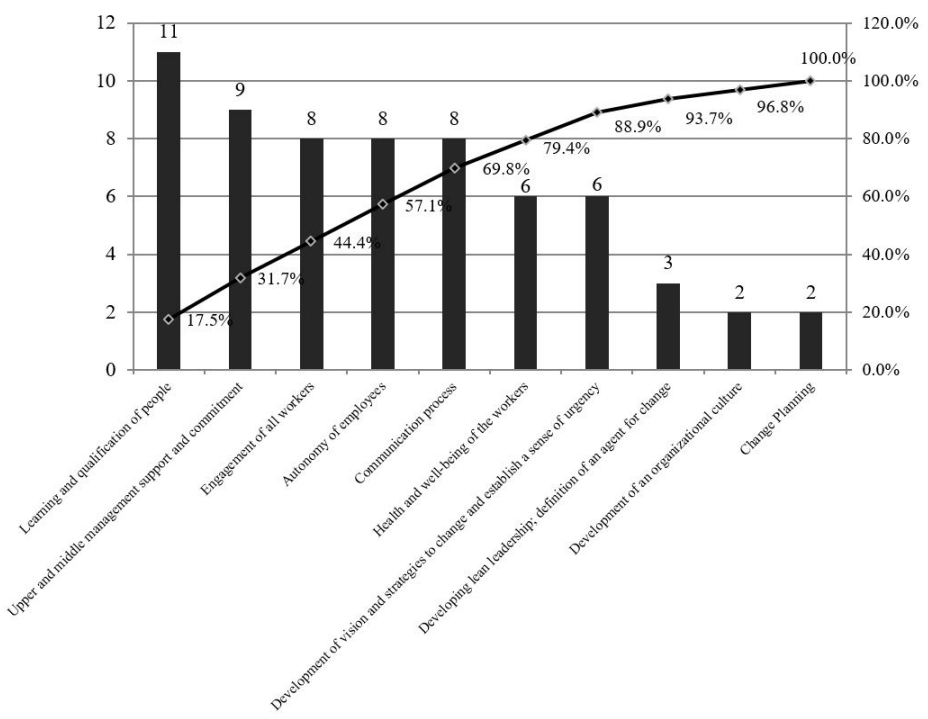

Figure 3. Factors evidenced in the literature. Source: Authors.

It was noted that learning and qualification of the people; upper and middle management support and commitment; engagement of all workers; autonomy of employees and communication process were the most quoted factors in the literature, which represents $69,8 \%$ of the total.

A network of relationship between the papers and their references was created based on results, in order to identify patterns of behavior and the interrelationship of the authors. Figure 4 illustrates it.

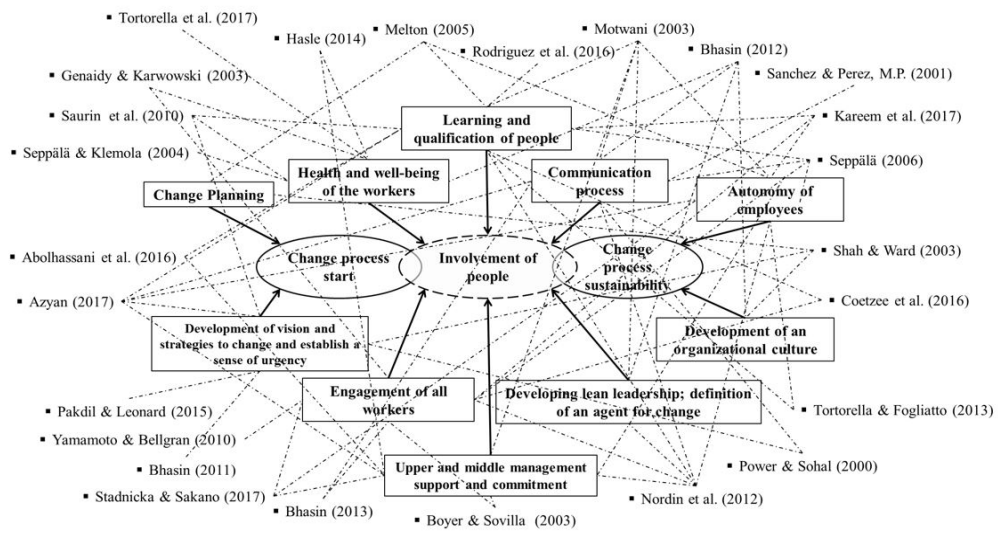

Figure 4. Network of relationship. Source: Authors.

The circles represent the different phases of the implementation process: Process start and sustainability of the change are connected by people involvement that must be continuous during all the phases. The 10 squares represent the contributory factors identified in the literature review. 
Change planning; development of a vision and strategies to change and establish a sense of urgency; were related to the initial phase of the change process. The factors learning and qualification of the people; health and well-being of the workers; communication process; engagement of all workers; Upper and middle management support and commitment; and developing lean leadership were related to the involvement of the people during both phases.

The autonomy of employees and development of an organizational culture, were related to the sustainability of the change process.

It was also observed that Nordin et al. (2012), Motwani (2003) and Seppälä (2006) were the authors with the highest number of factors mentioned in their studies.

This information allows a comparison between all factors and also supports the prioritization and signalization of the factors for future researches or to support and inspire industrial managers in the change process to a lean production system.

\section{Discussion of results}

Ten most recurrent factors in lean manufacturing implementation processes were evidenced, systematizing a set of lessons learned.

The study enables organizations to understand that factors can positively influence when analyzed in advance and managed correctly, but can also negatively impact the change management process.

Table 6 consolidates the contributory factors to change management identified as relevant in the literature to support the implementation of lean production systems.

Table 6. Contributing factors to the change process identified in the literature.

\begin{tabular}{|c|c|c|}
\hline & Contributory factors & Short Description \\
\hline 1 & $\begin{array}{l}\text { Learning and qualification } \\
\text { of people }\end{array}$ & $\begin{array}{l}\text { Training concepts and tools of lean manufacturing } \\
\text { contributes to a clearer understanding of this vision among } \\
\text { employees and stimulates participation in the process of } \\
\text { change, thus avoiding manifestations of resistance. }\end{array}$ \\
\hline 2 & $\begin{array}{l}\text { Upper and middle } \\
\text { management support and } \\
\text { commitment }\end{array}$ & $\begin{array}{c}\text { Upper and middle management should be responsible for } \\
\text { making lean deployment a priority within the business } \\
\text { environment. Managers are responsible for directing and } \\
\text { detailing the activities of each department involved in the } \\
\text { change. It is important that trainings are initially conducted } \\
\text { with managers and leaders so that they participate in the } \\
\text { implementation of the change. }\end{array}$ \\
\hline 3 & Engagement of all workers & $\begin{array}{c}\text { Managers should encourage employees to promote lean } \\
\text { manufacturing while at work by providing a continuous } \\
\text { variety of challenges and making them feel that their } \\
\text { qualifications are being used and that they are part of the } \\
\text { change process. } \\
\text { The creation of rewarding structures for results, the } \\
\text { development of payment systems and recognition of short- } \\
\text { term accomplishes also inspires motivation and } \\
\text { commitment. }\end{array}$ \\
\hline 4 & Employees Autonomy & $\begin{array}{l}\text { Qualifying and empowering workers develop autonomy as } \\
\text { they feel part of the change process and gain more } \\
\text { responsibilities. Establishing a policy of open suggestions } \\
\text { is also a way of developing people's autonomy. }\end{array}$ \\
\hline 5 & Communication process & $\begin{array}{l}\text { Creation of a single communication language with a more } \\
\text { understanding, open and direct approach to all employees, } \\
\text { characterizing participative management. The creation of }\end{array}$ \\
\hline
\end{tabular}


Table 6. Continued...

\begin{tabular}{|c|c|c|}
\hline & Contributory factors & Short Description \\
\hline & & $\begin{array}{l}\text { meeting routines, discussion of problems and suggestions, } \\
\text { creation of visual controls and production of indicators to } \\
\text { facilitate communication among sectors. }\end{array}$ \\
\hline 6 & $\begin{array}{l}\text { Health and well -being of } \\
\text { the workers }\end{array}$ & $\begin{array}{l}\text { Workers' health and well-being must be guaranteed by } \\
\text { managers throughout the change process. Lean production } \\
\text { system assigns more responsibilities to production staff } \\
\text { which can stimulate them but also increases workload and } \\
\text { consequently the levels of stress. }\end{array}$ \\
\hline 7 & $\begin{array}{l}\text { Development of vision and } \\
\text { strategies to change and } \\
\text { establish a sense of } \\
\text { urgency }\end{array}$ & $\begin{array}{l}\text { The company must have clear reasons to start Lean } \\
\text { implementation along with a well-defined change strategy. } \\
\text { The definition of a vision clarifies the direction of the } \\
\text { implementation and improves the alignment of the people } \\
\text { involved, effectively coordinating the actions taken. } \\
\text { Defining a sense of urgency early is important to generate } \\
\text { a sense of need for change in the process. }\end{array}$ \\
\hline 8 & $\begin{array}{l}\text { Developing lean } \\
\text { leadership; definition of an } \\
\text { agent for change }\end{array}$ & $\begin{array}{l}\text { Companies must develop leadership with clear and } \\
\text { consistent directions, and it is important to define a specific } \\
\text { professional to start the process and follow all stages of } \\
\text { development and dissemination. Change agents and all } \\
\text { leadership involved in the process must master the flow } \\
\text { techniques; pull production and perfection, also } \\
\text { participating in improvement activities. }\end{array}$ \\
\hline 9 & $\begin{array}{l}\text { Development of an } \\
\text { organizational culture }\end{array}$ & $\begin{array}{l}\text { Deploying a new production system can create a conflict } \\
\text { with the culture already in place and may delay the } \\
\text { adoption and performance of the new system. The process } \\
\text { of cultural transformation is maintained and reaches all } \\
\text { workers. }\end{array}$ \\
\hline 10 & Change Planning & $\begin{array}{c}\text { When implementing a new production system, managers } \\
\text { should know the internal and external characteristics of the } \\
\text { organization, understanding the individual differences in } \\
\text { place in order to develop a change planning. }\end{array}$ \\
\hline
\end{tabular}

Source: Authors.

\subsection{Learning and qualification of people}

Mentioned eleven times the learning and qualification of employees is the most frequent factor in the literature. For the TPS implementation, a total management system is required to develop human ability (Ohno, 1997).

The application of appropriate training in the basic concepts and principles of lean manufacturing can facilitate workers' understanding, motivating them and contributing to the innovation of the work culture and employee attitudes (Nordin et al., 2012). Training and instruction on ethical behavior can also support the engagement of the people with the change process (Kareem et al., 2017). It was observed in the studies carried out by Kareem et al. (2017), that there is a difference between the instructions requested by the leaders and those that were taught in the trainings to the workers.

Leaders and supervisors should be the first ones to take the training in order to become specialists so that they contribute to the implementation of change (Motwani, 2003). In the study carried out by Coetzee et al. (2016), in most of the implementation strategies analyzed trainings were performed just for workers and not for leaders, this can be consider as one of the factors that lead to the failure of the change process. Workers qualification is the basis for any change initiative and should be carried out over the long term (Dombrowski \& Mielke, 2013; Tortorella \& Fogliatto, 2013). 
Training and education develops autonomy as the transformation of production occurs by giving workers activities beyond their original scope (Tortorella \& Fogliatto, 2013).

Azyan et al. (2017) noted in their studies that the company with the best result after the change promoted extensive trainings with the support of an external training to provide a clear communication of the objectives and concepts of lean manufacturing.

One of the main resistances found in the implementation of a change process is the difficulty of adapting concepts and practices (Saurin et al., 2010).

According to Abolhassani et al. (2016), lean practices are not properly used due to the lack of knowledge and skills of the people.

The creation of multi-tasking teams that have more responsibilities over production also helps in the successful implementation of lean manufacturing in organizations (Melton, 2005). The adoption of training for workers contributes to the development of skills linked to multifunctionality (Seppälä, 2006).

The importance of defining a coherent and coordinated strategy with human resources management is mandatory to a successful transition, since it helps to develop employee skills and increase retention in the company (Rodriguez et al., 2016).

\subsection{Upper and middle management support and commitment}

Upper and middle management support and commitment presents 9 quotations in the literature. Leadership and management commitment are important factors in lean manufacturing, and the manager is responsible for directing and detailing the activities of each department involved in the change, offering support and allocating necessary support, for example, hiring a coaching (Nordin et al., 2012; Azyan et al., 2017; Abolhassani et al., 2016; Kareem et al., 2017).

The managers must be engaged to making lean manufacturing a priority within the business environment (Boyer \& Sovilla, 2003; Motwani, 2003).

It is important to have a trustworthy relationship between management and operators during the implementation process (Hasle, 2014). One of the practices observed by Seppälä (2006) was the creation of a meeting routine with the participation of the manufacturing manager and supervisor, creating an opportunity to improve the relationship between the two levels of workers.

According to Dombrowski \& Mielke (2013), the key to succeed when implementing a change process is the involvement of workers in daily improvements, which can be achieved by upper and middle participative leadership.

\subsection{Engagement of all workers}

The engagement of the workers is quoted eight times in the literature. Human capital is an important factor for organizations' long-term positive performance (Genaidy \& Karwowski, 2003).

The professionals tend to do only activities related to their own interests and it is important to understand their view in the process of change in order to develop actions to satisfy their interests as the transition advances (Boyer \& Sovilla, 2003).

Companies should prepare their employees to use their time to promote lean manufacturing and provide a continuous variety of challenges so that employees feel 
that their qualifications are being used and that they are being valued by the various knowledge acquired, thus facilitating the acceptance of the process. (Womack et al., 1997; Nordin et al., 2012). Employees should be aware of the changes in their way of working to be able to contribute to it (Yamamoto \& Bellgran, 2010).

Coetzee et al. (2016) analyzed different strategies of lean manufacturing implementation, and in none of the cases the involvement of the people to identify and solve problem was observed, which was pointed out as the main reason for the failure of the processes.

In order to facilitate people's commitment, some actions can be taken such as creating a reward structure with a payment system or a performance measurement indicator. Recognizing short-term achievements also support and motivate teams (Seppälä, 2006; Nordin et al., 2012; Bhasin, 2013; Stadnicka \& Sakano, 2017).

\subsection{Autonomy of employees}

The autonomy of the employees is also mentioned eight times in the analyzed literature. This factor is directly related to learning and empowerment of people (Melton, 2005; Nordin et al., 2012; Tortorella \& Fogliatto, 2013). It is a critical transition when managers become coaches and proactive employees (Womack \& Jones, 1998). Due to traditional management practices, managers are reluctant to give employees autonomy (Kareem et al., 2017).

In the study of Seppälä (2006), even though the organization adopted the division of labor among cell workers, supervisors and maintenance staff to increase work autonomy, the result was not as planned due to frequent changes in the initial plan. The roles of the manufacturing manager and supervisor still dominated, while the cell manager had his role reduced.

The goal of lean manufacturing is to bring responsibility and autonomy to the bottom of the organizational pyramid. This responsibility can mean freedom to control one's own work, but also an increase in fear of committing wrongs (Womack et al., 1997).

In the research carried out by Stadnicka \& Sakano (2017) and Motwani (2003), in the implementation approach analyzed the authors also observed the policy of open suggestions as a way to develop the autonomy.

According to Azyan et al. (2017), the development of employees' autonomy with daily decision-making processes and open communication contributed to create a pleasant work culture, reduce absenteeism rates, and increase productivity.

\subsection{Communication process}

Mentioned eight times, the communication process is the most frequent factor in the literature. The improvement team and the entire workforce must be able to see change in the organization and leaders must be able to pass on knowledge and information to others (Womack \& Jones, 1998).

In addition to adopting the common tools of lean manufacturing system, companies must create a single communication language with a more understanding, open and direct approach to all employees, characterizing participative management (Motwani, 2003; Power \& Sohal, 2000; Seppälä, 2006; Bhasin, 2012; Nordin et al., 2012; Dombrowski \& Mielke, 2013; Azyan et al., 2017). 
Some companies adopt initiatives such as meeting routines to exchange information, discuss problems and suggestions to create a trustworhty environment among employees (Motwani, 2003, Seppälä, 2006). The creation of visual controls and production indicators also helps to control the process and facilitate communication among the company's sectors (Martínez Sánchez \& Pérez Pérez, 2001; Motwani, 2003). The dissemination of positive results can also help involving human resources in the process of change (Bhasin, 2013).

\subsection{Health and well-being of the workers}

The health and well-being of the worker is evidenced with six quotations in the literature. An important aspect related to lean production system is that the workload increases due to the changes. Some professionals may find the new way of working more stimulating what leads to an increase in their productivity. At the same time, the activity can be considered more stressful due to the increased responsibilities attributed to the employees (Womack et al., 1997).

Hasle (2014) investigated the relationship between the implementation of lean practices and the benefits to the working environment and to the health and well-being of the workers. Negative effects were observed mainly in relation to manual workers with low skills in the automotive industry and other assembly lines. One of the problems is the worker's perspective that lean manufacturing tends to reduce the amount of manpower needed for production

Concerns about the increased level of stress related to lean manufacturing implantation were observed in the literature (Genaidy \& Karwowski, 2003; Bhasin, 2012).

The ergonomic aspects of the workstations must be taken into account to implement lean tools, as they affect the muscular, cognitive and emotional demands of the workers (Tortorella et al., 2017).

Seppälä \& Klemola (2004) state that work in the lean production system is burdened with continuous pressure and stress. Workers alternate repetitive tasks, which mean more multitasking rather than multi-skills. In this study, the adoption of lean manufacturing principles had a greater impact on employees who supervise workers directly linked to production due to the increase of their responsibilities, new activities, and the need to master new computational tools, which presented a great challenge.

\subsection{Development of vision and strategies to change and establish a sense of urgency}

The development of a vision, strategy to change and establishment of a sense of urgency is also quoted six times in the literature. The creation of a practical organization strategy can channel the flow of value related to the change is important to sustain the efforts of the first deployment (Womack \& Jones, 1998).

According to Kotter (1997), the vision must meet three objectives: (i) Clarify the general direction of the deployment; (ii) Facilitate major changes by motivating actions that do not directly address the immediate interests of people; (iii) The vision creates coalition and alignment of the involved people, coordinating effective ways to develop the actions. 
The implementation of lean manufacturing system should be justified and clear in order to initiate the transition process. Some of the main reasons are (Saurin et al., 2010): (i) Improving competitiveness; (ii) Adapting lean production to fight critical production problems; (iii) Customer requirements; (iv) Reduction of waste; (v) Capacity increase without increasing workforce; (vi) Increase the profit margin; (vii) Reducing lead time to increase sales; (viii) Step out of the comfort zone anticipating future difficulties; (ix) Continuous improvement features.

The implementation of lean manufacturing requires the development of processes that can be sustained over time with a well traced strategy of change and a wide applicability by the sectors of the organization (Bhasin, 2011).

The chances of success in the transition process vary according to each organization and are closely related to its structure, systems, strategies and human resources (Ohno, 1997). The challenge of deploying and sustaining any lean manufacturing process is the need to identify in advance which organizational structure must exist to ensure success (Pakdil \& Leonard, 2015). The transition strategy must be coherent and coordinated with human resources management for lean manufacturing to take hold (Power \& Sohal, 2000; Shah \& Ward, 2003; Pakdil \& Leonard, 2015).

Azyan et al. (2107) noted in their studies, that in the company with successful implementation of lean, the motivation for change was clearly aligned with the organization's strategic objectives, creating a sense of purpose and facilitating people's engagement.

In addition to the definition of strategy, the literature also points to the importance of defining the sense of urgency to initiate change, since the implementation of improvements without the sense of need tends to have a low sustainability and failure (Kotter, 1997; Womack \& Jones, 1998).

\subsection{Developing lean leadership; definition of an agent to support change}

Lean leadership and definition of a change agent are quoted three times in the literature analyzed. There are differences between the concepts of management and leadership. According to Kotter (1997), management can be defined as a well-functioning system of people and technologies while leadership is defined as processes that create organizations and adapt them to modify circumstances significantly. Leadership sets the future, aligns people to that vision, and inspires action despite obstacles.

Lean leaders often go to the plant floor to understand the processes effectively in order to take the best decisions, a principle known as Gemba (Womack, 2011).

The first step to achieving positive results is to define a change agent, a professional specifically oriented to initiate the process and to follow all the stages of dissemination development (Womack \& Jones, 1998). Change agents must have the power to make decisions to highlight the transition progress and discuss the importance of problems as barriers to change within an organization (Herron \& Hicks, 2008).

Nordin et al. (2012) understand that leadership must have clear and consistent directions to create a strong team of change agents. The professionals who lead the projects must be highly committed and have the skills, abilities and attitudes to implement the tools, techniques and lean processes (Motwani, 2003; Herron \& Hicks, 2008; Bhasin, 2012; Nordin et al., 2012). Womack \& Jones (1998) also argue that change agents and all leaders involved in the process must master the flow techniques, pull production and perfection, also taking part in improvement activities. 
Dombrowski \& Mielke (2013) based their research on five basic principles of lean leadership: (i) Culture of continuous improvement; (ii) Pursuit of perfection; (iii) Self-development: Models of lean leaders; (iv) Qualification: Long-term employee development; (v) Gemba: Plant floor management; first-hand knowledgebased decisions; (vi) Hoshin Karin: Customer focus; (vii) Alignment of objectives at all levels.

\subsection{Development of an organizational culture}

The development factor of an organizational culture is mentioned twice in the literature. The principles and tools developed and used by the Japanese, when deployed in a different organizational environment can create a conflict with the culture already in place; this divergence may delay the adoption and performance of the process. Companies wishing to successfully implement lean cannot afford negative cultures (Womack \& Jones, 2005).

The application of lean manufacturing tools should be understood considering the cultural context of the organization (Shah \& Ward, 2003). According to Bhasin (2012), it is necessary to define a controlled and systematized strategy focused on the organization's culture. By focusing on tangible results, companies forget the intangible aspects related to culture and changes.

Womack \& Jones (1998) believe that after making the first improvements it is necessary to transpose the logic of lean into the other activities linked to production to ensure that the process of cultural transformation is maintained and reaches all workers. Organizations should create a mindset in which temporary failure to reach the proposed goal is acceptable, but the volume of performance improvements must never be considered enough (Womack \& Jones, 1998).

\subsection{Change planning}

The transition planning is also quoted twice. It depends on the knowledge of internal and external characteristics of an organization as well as the understanding of the existing individual differences.

According to Melton (2005), the lean production system can be applied in any business process within companies. The challenge is to know the extent to which the organization is known such as ways of working, which business process customer value and how the business operates and needs to operate. The success of the implementation depends on the characteristics of the organization for not all companies shall apply the same group of practices (Shah \& Ward, 2003).

\section{Conclusions and suggestions for future studies}

This research aims the identification of the main factors which affect the transition management while implementing lean manufacturing using the revision of the scientific literature to gather an information collection.

The systematization of such practices can contribute to improve the performance of change processes caused by the implementation of lean production systems as far as they involve the development of technical and social factors. 
In order to meet the objective proposed by this paper, the existence of change management practices was observed to support the implementation of lean production system.

In a synthesized form, 10 factors were evidenced: learning and qualification of people; upper and middle management support and commitment; engagement of all workers; autonomy of employees; communication process; health and well-being of the workers; development of vision and strategies to change and establish a sense of urgency; developing lean leadership and definition of an agent for change; development of an organizational culture; and change Planning.

However, it is important to emphasize that the chances of success varies according to each organization depending on its structure, systems, strategies and human resources. Prior identification of such characteristics and structure is necessary since not all companies apply the same set of practices (Shah \& Ward, 2003; Melton, 2005; Al-Haddad \& Kotnour, 2015; Pakdil \& Leonard, 2015).

The research was carried out using robust databases, but the results found do not exhaust the possibility of identifying new factors, based on future research, considering other journals bases which were not contemplated in this study, as well as research on $\mathrm{PhD}$ thesis bases and Master Thesis. Additionally, you can extend the search to other languages.

In addition, this study uses the webbliomining technique proposed by Costa (2010) and other techniques of systematic literature collection such as prism protocol or Cochrane which are commonly used by other areas of knowledge, such as health sciences.

In order to carry out future research, it is suggested to develop case studies in organizations which have implemented lean manufacturing to highlight main factors that positively and negatively contributed to the change process, emphasizing those already identified in this research and indicating new factors. In addition, it would be important to collect the main factors that have contributed to the success or failure from the perception of all parties concerned.

\section{References}

Abolhassani, A., Layfield, K., \& Gopalakrishnan, B. (2016). Lean and US manufacturing industry: popularity of practices and implementation barriers. International Journal of Productivity and Performance Management, 65(7), 875-897. http://dx.doi.org/10.1108/IJPPM-10-2014-0157.

Al-Haddad, S., \& Kotnour, T. (2015). Integrating the organizational change literature: a model for successful change. Journal of Organizational Change Management, 28(2), 234-262. http://dx.doi.org/10.1108/JOCM-11-2013-0215.

Armenakis, A. A., \& Bedeian, A. G. (1999). Organizational change: a review of theory and research in the 1990s. Journal of Management, 25(3), 293-315. http://dx.doi.org/10.1177/014920639902500303.

Azyan, Z. H. A., Pulakanam, V., \& Pons, D. (2017). Success factors and barriers to implementing lean in the printing industry: a case study and theoretical framework. Journal of Manufacturing Technology Management, 28(4), 458-484. http://dx.doi.org/10.1108/JMTM-05-2016-0067.

Bamford, D., Forrester, P., Dehe, B., \& Leese, R. G. (2015). Partial and interative lean implementation: two case studies. International Journal of Operations \& Production Management, 35(5), 702-727. http://dx.doi.org/10.1108/IJOPM-07-2013-0329. 
Bardin, L. (1977). Análise de conteúdo. Lisboa: Editora Edições 70.

Battilana, J., Gilmartin, M., Sengul, M., Pache, A. C., \& Alexander, J. A. (2010). Leadership competencies for implementing planned organizational change. The Leadership Quarterly, 21(3), 422-438. http://dx.doi.org/10.1016/j.leaqua.2010.03.007.

Bhasin, S. (2011). Performance of organisations treating lean as an ideology. Business Process Management Journal, 17(66), 986-1011. http://dx.doi.org/10.1108/14637151111182729.

Bhasin, S. (2012). An appropriate change strategy for lean success. Management Decision, 50(3), 439-458. http://dx.doi.org/10.1108/00251741211216223.

Bhasin, S. (2013). Impact of corporate culture on the adoption of the Lean principles. International Journal of Lean Six Sigma, 4(2), 118-140. http://dx.doi.org/10.1108/20401461311319329.

Box, S., \& Platts, K. (2005). Business process management: establishing and maintaining project alignment. Business Process Management Journal, 11(4), 370-387. http://dx.doi.org/10.1108/14637150510609408.

Boyer, M., \& Sovilla, L. (2003). How to Identify and Remove the Barriers for a Successful Lean Implementation. Journal of Ship Production, 19(2), 116-120.

Chu, K. F. (2003). An organizational culture and the empowerment for change in SMEs in the Hong Kong manufacturing industry. Journal of Materials Processing Technology, 139(1-3), 505-509. http://dx.doi.org/10.1016/S0924-0136(03)00527-2.

Coetzee, R., Van der Merwe, K., \& Van Dyk, L. (2016). Lean implementation strategies: how are the Toyota way principles addressed? South African Journal of Industrial Engineering, 27(3), 79-91. http://dx.doi.org/10.7166/27-3-1641.

Costa, H. G. (2010). Modelo para webibliomining: proposta e caso de aplicação. Revista da $F A E, 13(1), 115-126$. Retrieved in 2016, January 18, from http://www.unifae.br/publicacoes/v.13_012010.pdf\#page=119

Dombrowski, U., \& Mielke, T. (2013). Lean Leadership fundamental principles and their application. Procedia CIRP, 7, 569-574. http://dx.doi.org/10.1016/j.procir.2013.06.034.

Ford, J. D., Ford, L. W., \& Mcnamara, R. T. (2002). Resistance and the background conversations of change. Journal of Organizational Change Management, 15(2), 105-121. http://dx.doi.org/10.1108/09534810210422991.

Furlan, A., Vinelli, A., \& Dal Pont, G. 2011). Complementarity and lean manufacturing bundles: an empirical analysis. International Journal of Operations \& Production Management, 31(8), 835-850. http://dx.doi.org/10.1108/01443571111153067.

Genaidy, A., \& Karwowski, W. (2003). Human performance in lean production environment: critical assessment and research framework. Human Factors and Ergonomics in Manufacturing, 13(4), 317-330. http://dx.doi.org/10.1002/hfm.10047.

Goodman, E., \& Loh, L. (2011). Organizational change: a critical challenge for team effectiveness. Business Information Review, 28(4), 242-250.

http://dx.doi.org/10.1177/0266382111427087.

Hasle, P. (2014). Lean production - an evaluation of the possibilities for an employee supportive lean practice. Human Factors and Ergonomics in Manufacturing \& Service Industries, 24(1), 40-53. http://dx.doi.org/10.1002/hfm.20350.

Herron, C., \& Hicks, C. (2008). The transfer of selected lean manufacturing techniques from Japanese automotive manufacturing into general manufacturing (UK) through change agents. Robotics and Computer-integrated Manufacturing, 24(4), 524-531. http://dx.doi.org/10.1016/j.rcim.2007.07.014.

Hill, N. S., Seo, M. G., Kang, J. H., \& Taylor, M. S. (2012). Building employee commitment to change across organizational levels: the influence of hierarchical distance and direct managers' transformational leadership. Organization Science, 23(3), 758-777. http://dx.doi.org/10.1287/orsc.1110.0662. 
Kareem, J. A. H., Askira, P. S. M. A., \& Hussain, F. (2017). Critical issues in lean manufacturing programs: A case study in Kurdish iron \& steel factories. Cogent Engineering, 4(1), 1-14. http://dx.doi.org/10.1080/23311916.2017.1386853.

Kotter, J. P. (1997). Liderando mudança (20 ed.). Rio de Janeiro: Elsevier.

Liker, J. K. (2004), The Toyota Way: 14 Management principles from the World's Greatest Manufacturer. New York: McGraw-Hill.

Lines, B. C., Sullivan, K. T., Smithwick, J. B., \& Mischung, J. (2015). Overcoming resistance to change in engineering and construction: change management factors for owner organizations. International Journal of Project Management, 33(5), 1170-1179. http://dx.doi.org/10.1016/j.jproman.2015.01.008.

Maheshwari, S., \& Vohra, V. (2015). Identifying critical HR practices impacting employee perception and commitment during organizational change. Journal of Organizational Change Management, 28(5), 872-894. http://dx.doi.org/10.1108/JOCM-03-2014-0066.

Martínez Sánchez, A., \& Pérez Pérez, M. (2001). Lean indicators and manufacturing strategies. International Journal of Operations \& Production Management, 21(11), 1433-1452. http://dx.doi.org/10.1108/01443570110407436.

Melton, T. (2005). The benefits of lean manufacturing: What Lean Thinking has to Offer the Process Industries. Chemical Engineering Research \& Design, 83(6), 662-673. http://dx.doi.org/10.1205/cherd.04351.

Morgan, D., \& Zeffane, R. (2003). Employee involvement, organizational change and trust in management. International Journal of Human Resource Management, 14(1), 55-75. http://dx.doi.org/10.1080/09585190210158510.

Motwani, J. (2003). A business process change framework for examining lean manufacturing: a case study. Industrial Management \& Data Systems, 103(5), 339-346. http://dx.doi.org/10.1108/02635570310477398.

Nordin, N., Deros, B. M., Wahab, D. A., \& Rahman, M. N. (2012). A framework for organisational change management in lean manufacturing implementation. International Journal of Services and Operations Management, 12(1), 101-117. http://dx.doi.org/10.1504/IJSOM.2012.046676.

Ohno, T. (1997). O sistema Toyota de produção: além da produção em larga escala. Porto Alegre: Bookman.

Pakdil, F., \& Leonard, K. M. (2015). The effect of organizational culture on implementing and sustaining lean processes. Journal of Manufacturing Technology Management, 26(5), 725743. http://dx.doi.org/10.1108/JMTM-08-2013-0112.

Parish, T. J., Cadwallader, S., \& Busch, P. (2008). Want to, need to, ought to: employee commitment to organizational change. Journal of Organizational Change Management, 21(1), 32-52. http://dx.doi.org/10.1108/09534810810847020.

Power, D., \& Sohal, A. S. (2000). Human resource management strategies and practices in Just-In-Time environments: australian case study evidence. Technovation, 20(7), 373-387. http://dx.doi.org/10.1016/S0166-4972(99)00151-0.

Rodriguez, D., Buyens, D., Van Landeghem, H., \& Lasio, V. (2016). Impact of Lean production on perceived job autonomy and job satisfaction: an experimental study. Human Factors and Ergonomics in Manufacturing \& Service Industries, 26(2), 159-176. http://dx.doi.org/10.1002/hfm.20620.

Rusly, F. H., Sun, P. Y. T., \& Corner, J. L. (2015). Change readiness: creating understanding and capability for the knowledge acquisition process. Journal of Knowledge Management, 19(6), 1204-1223. http://dx.doi.org/10.1108/JKM-02-2015-0092.

Saurin, T. A., Ribeiro, J. L. D., \& Marodin, G. A. (2010). Identificação de oportunidades de pesquisa a partir de um levantamento da implantação da produção enxuta em empresas 
do Brasil e do exterior. Gestão \& Produção, 17(4), 829-841.

http://dx.doi.org/10.1590/S0104-530X2010000400015.

Seppälä, P. (2006). How to Carry Out Sustainable Change? An Analysis of Introducing Manufacturing Cells in a Finnish Engineering Company. Human Factors and Ergonomics in Manufacturing, 16(1), 17-37. http://dx.doi.org/10.1002/hfm.20040.

Seppälä, P., \& Klemola, S. (2004). How do employees perceive their organization and job when companies adopt principles of lean production? Human Factors and Ergonomics in Manufacturing, 14(2), 157-180. http://dx.doi.org/10.1002/hfm.10059.

Shah, R., \& Ward, P. T. (2003). Lean manufacturing: context, practice bundles, and performance. Journal of Operations Management, 21(2), 129-149. http://dx.doi.org/10.1016/S0272-6963(02)00108-0.

Shokri, A., Waring, T. S., \& Nabhani, F. (2016). Investigating the readiness of people in manufacturing SMEs to embark on Lean Six Sigma projects An empirical study in the German manufacturing sector. International Journal of Operations \& Production Management, 36(8), 850-878. http://dx.doi.org/10.1108/JJOPM-11-2014-0530.

Shook, J. (2010). How to change a culture: lessons from NUMMI. MIT Sloan Management Review, 51(2), 63-68.

Silva, G. B., \& Costa, H. G. (2015). Mapeamento de um núcleo de partida de referências em Data Mining a partir de periódicos publicados no Brasil. Gestão \& Produção, 22(1), 107118. http://dx.doi.org/10.1590/0104-530X792-13.

Stadnicka, D., \& Sakano, K. (2017). Employees motivation and openness for continuous improvement: comparative study in polish and japanese companies. Management and Production Engineering Review, 8(3), 70-86. http://dx.doi.org/10.1515/mper-2017-0030.

Tortorella, G. L., \& Fogliatto, F. S. (2013). Gestão da Mudança para um Sistema de Produção Enxuta: estado da arte e direções de pesquisa. Espacios, 34(8),7. Retrieved in 2016, January 18, from http://www.revistaespacios.com/a13v34n08/13340807.html

Tortorella, G. L., Vergara, L. G. L., \& Ferreira, E. P. (2017). Lean manufacturing implementation: an assessment method with regards to socio-technical and ergonomics practices adoption. International Journal of Advanced Manufacturing Technology, 89(1), 3407-3418. http://dx.doi.org/10.1007/s00170-016-9227-7.

Van Dun, D. H., \& Wilderom, C. P. M. (2016). Lean-team effectiveness through leader values and members'informing. International Journal of Operations \& Production Management, 36(11), 1530-1550. http://dx.doi.org/10.1108/lJOPM-06-2015-0338

Walker, H. J., Armenakis, A. A., \& Bernerth, J. B. (2007). Factors influencing organizational change efforts. Journal of Organizational Change Management, 20(6), 761-773. http://dx.doi.org/10.1108/09534810710831000.

Womack, J. (2011). Gemba walks. Cambridge: Lean Enterprise Institute.

Womack, J., \& Jones, D. T. (1994). From lean production to the lean enterprise. Harvard Business Review, 72(2), 93-103.

Womack, J., \& Jones, D. T. (1998). A mentalidade enxuta nas empresas (5. ed.). Rio de Janeiro: Campus.

Womack, J., \& Jones, D. T. (2003). Lean Thinking: Banish Waste and Create Wealth for Your Corporation (2 ed.). New York: Simon and Schuster.

Womack, J., \& Jones, D. T. (2005). Lean solutions. London: Simon and Schuster.

Womack, J., Jones, D. T., \& Ross, D. (1997). A máquina que mudou o mundo (14 ed.). Rio de Janeiro: Campus.

Yamamoto, Y., \& Bellgran, M. (2010). Fundamental mindset that drives improvements towards lean production. Assembly Automation, 30(2), 124-130.

http://dx.doi.org/10.1108/01445151011029754. 